\title{
Nannostratigraphy and Palaeoecology of the Uppermost Mozduran Formation in the Jozak Section in West Kopet-Dagh (NE Iran)
}

\author{
Mohammad Anvar Moheghy ${ }^{*}$, Fatemeh Hadavi \\ Department of Geology, Faculty of Science, Ferdowsi University of Mashhad, Mashhad, Iran \\ Email: ${ }^{*}$ moheghy@gmail.com
}

Received November 2, 2013; revised December 3, 2013; accepted January 1, 2014

Copyright (C) 2014 Mohammad Anvar Moheghy, Fatemeh Hadavi. This is an open access article distributed under the Creative Commons Attribution License, which permits unrestricted use, distribution, and reproduction in any medium, provided the original work is properly cited. In accordance of the Creative Commons Attribution License all Copyrights (C) 2014 are reserved for SCIRP and the owner of the intellectual property Mohammad Anvar Moheghy, Fatemeh Hadavi. All Copyright (C) 2014 are guarded by law and by SCIRP as a guardian.

\section{ABSTRACT}

This paper discusses the biostratigraphy and palaeoecology of calcareous nannofossils of the uppermost Mozduran Formation in the Jozak section in west Kopet-Dagh basin. The Mozduran Formation consists of white to grey Limestone. In the studied sections, samples are taken and prepared with smear slides. In the Jozak section, 17 species have been determined. Based on nannoplanktons and as a result of biostratigraphy studies, the nannofossil standard zones (CC4) are identified. According to this zone, the age of the studied thickness is Early Hauterivian in this section in west Kopet-Dagh basin. The presence of warm water indicators (Nannoconus, Watznaueria, Lithraphidites) suggests warm surface water conditions in the studied thickness. In the Jozak section based on Nannoconus spp., low fertility conditions are suggested. The studied area is deposited in low to middle latitudes and shallow marine environments.

\section{KEYWORDS}

Nannostratigraphy; Paleoecology; Mozduran; Shurijeh; Kopet-Dagh; Iran

\section{Introduction}

Kopet-Dagh has a complete Cretaceous sedimentary succession comprising marine shales, marly limestone and subordinate sandstones. This sequence seems to represent all stages of the Cretaceous [1].

The earliest paleontological studies of the Cretaceous Formations of the Kopet-Dagh and particularly Mozduran Formation have been focused on the base on foraminifera.

The first comprehensive research on the calcareous nannofossils of the Mozduran Formation in the east of Kopet-Dagh in the Mozduran and Taherabad sections was undertaken by Hadavi and Khodadadi [2].

Based on Calcareous nannofossils, the age of the boundary between the Mozduran and Shurijeh Formations is Early Berriasian in the Mozduran section and Late Valanginian in the Taherabad section.

\footnotetext{
"Corresponding author.
}

All of previous studies were inclusive study of whole formation, but in the present study, for the first time, biostratigraphy and paleoecology of the uppermost Mozduran Formation in the Jozak section in west KopetDagh basin were discussed.

\section{Geological Setting}

The Mozduran Formation consists of shallow marine dolomite and thin gypsum layers in the eastern part of Kopeh-Dagh basin, suggesting that the basin is shallower in the east than the west [3]. At Mozduran pass, the type locality, the unit is about $500 \mathrm{~m}$ thick and overlies the Mozduran Formation with an apparent unconformity and is overlain by red clastic beds of Shurijeh Formation. From the type locality southeastwards the thickness of the Mozduran Formation decreases considerably and the limestone and dolomites are replaced by sandstones, red clastic rocks, and evaporites similar to the Shurijeh li- 
thology [4].

The Shurijeh Formation consists of conspicuous red beds, mainly sandstones and conglomerates; in more northwestern outcrops the unit contains also some thin gypsom layers and oolithic Limestone bands. Later, The Shurijeh Formation was found to interfinger laterally with the overlying Tirgan Formation northwest of the Shurijeh type area. The thickness of the Shurijeh Formation varies from about 250 to $900 \mathrm{~m}$ [3].
The detailed observation of nannofossils gave us very useful data, so this study is based on microscopic analyses of the calcareous nannoplanktons found in the samples that were taken from the boundary between Mozduran and Shurijeh Formations in west Kopet-Dagh (Figure 1).

The thickness of the samples was $60 \mathrm{~m}$ in this section and contained white to grey Limestone and brown to red alternation of shale and sandstone (Figure 2).

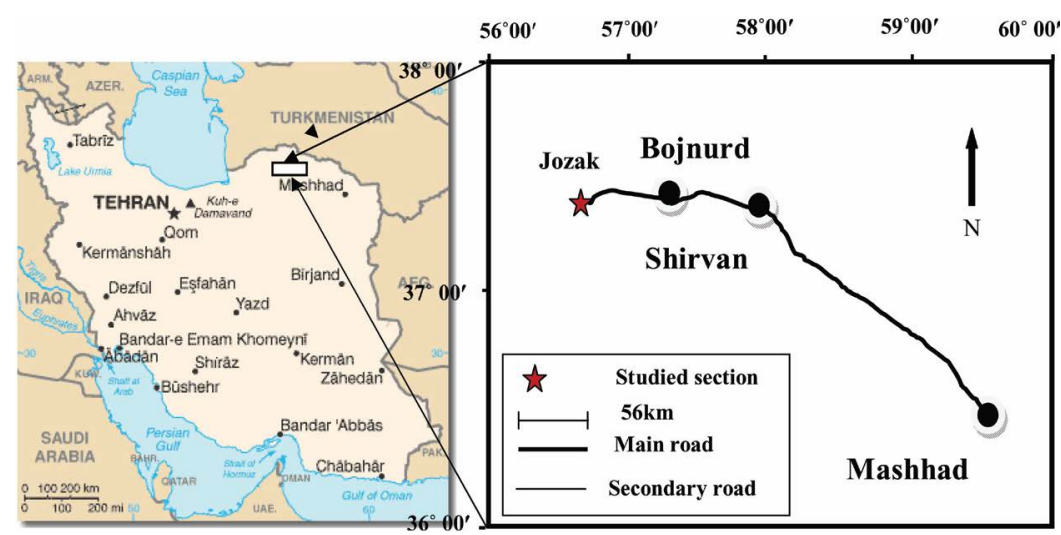

Figure 1. Geographical situation of studied section.

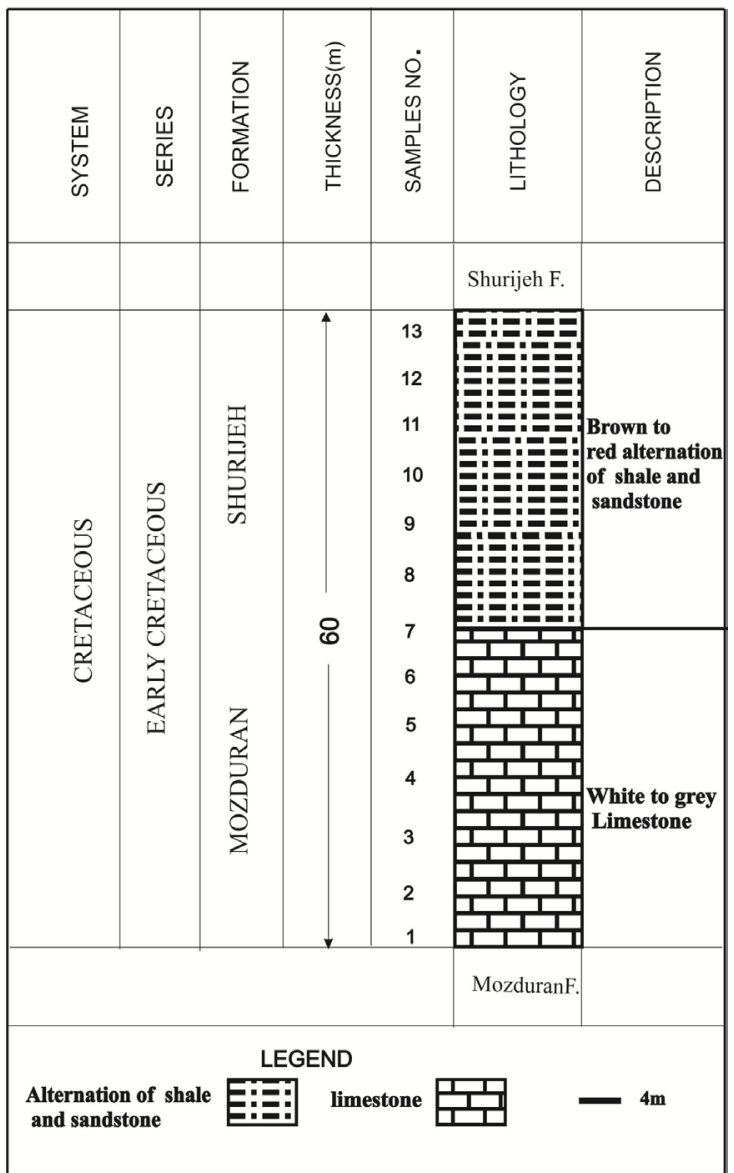

Figure 2. Lithostratigraphic column of the boundary between Mozduran and Shurijeh Formations in the Jozak section. 


\section{Samples and Methods}

A total of 13 samples from the boundary between Mozduran and Shurijeh Formations were collected. For calcareous nannofossils preparation, a small surface of the sample was scraped with a razor blade (the razor used in these preparations was washed with distilled water between samples) until a fresh surface was obtained, and then, a small amount of sediment was mixed with a drop of distilled water and spread out evenly across a microscope cover glass (we paid attention to the homogeneity of the deposition so that calcareous nannofossils are evenly distributed on the slide); after this, suspension has dried up on a hot plate. The work area and the hot plate that were used in making the smear slides were cleaned using $10 \% \mathrm{HCl}$ between sample preparations. This was done to reduce the chance of contamination. The examination of nannofloras was performed by using a light microscope at $1250 \times$ magnification. Digital images were captured with a digital camera. All images were taken in either cross polarized light (XPL) or plane polarized light (PPL), they are shown on the (Plates 1-3). At first all calcareous nannofossil specimens encountered were identified following the taxonomic schemes of several renowned authors [5-9] and then counted for the purpose of palaeoecological studies. For counting in some purview, all nannofossil species were counted. The percentage of each species for drawing the diagrams was calculated (Tables 1, 2).

\section{Nannofossils Biostratigraphy and Zonation}

In the boundary between Mozduran and Shurijeh Formations, biostratigraphic studies of calcareous nannofossils have allowed the identification of calcareous nannofos-

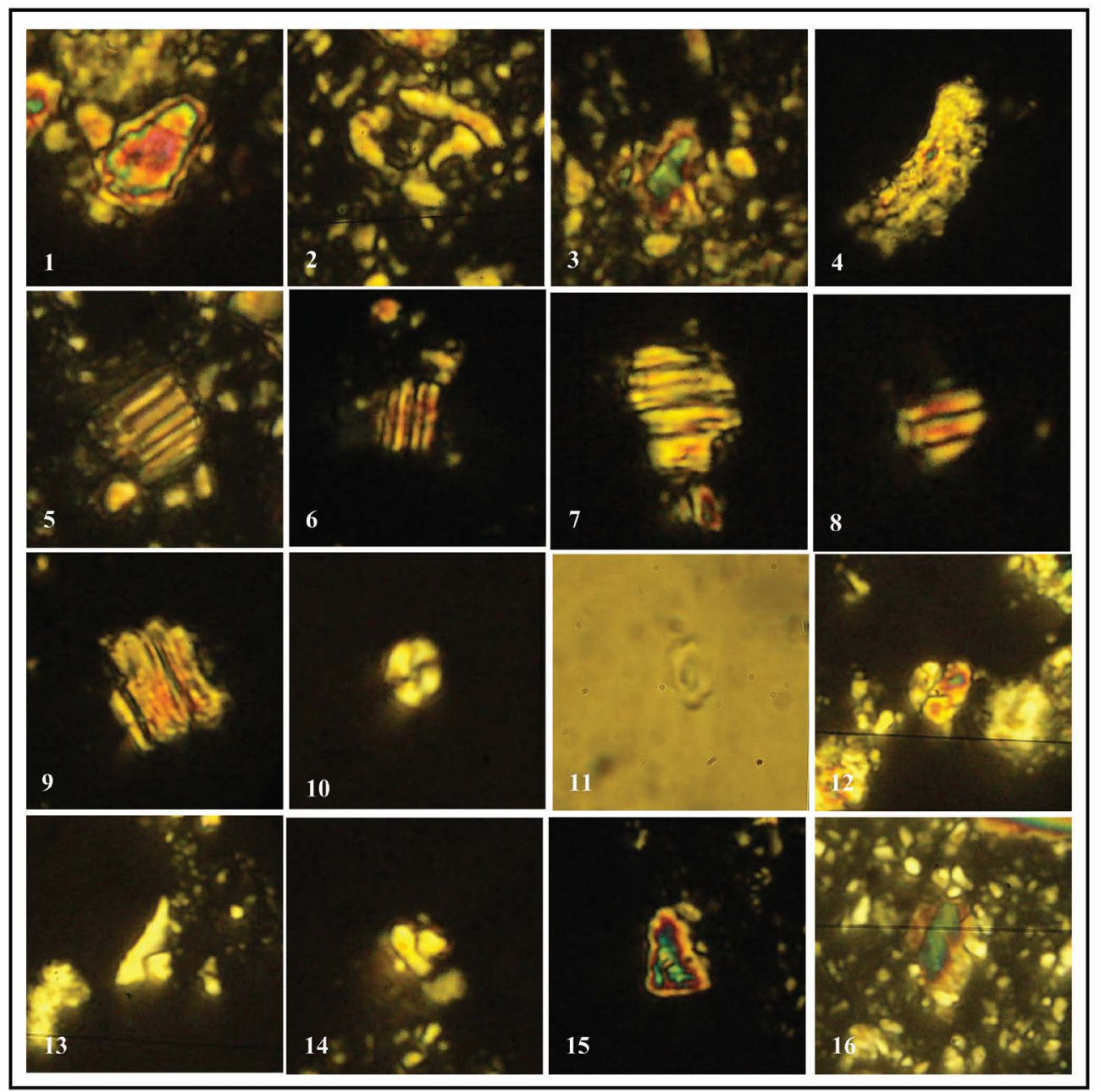

Plate 1. All figures $\times 1250$. (1): Nannoconus kamptneri, sample No. 5; (2): Zeugrhabdotus erectus, sample No. 1; (3, 4): Nannoconus steinmannii, 3 sample No. 5, 4 sample No. 8; (5-7): Conusphaera mexicana, 5 sample No. 3, 6 sample No. 7, 7 sample No. 10; (8, 9): Nannoconus dolomiticus, 8 sample No. 2 , 9 sample No. 7; $(10,11)$ : Watznaueria barnesae, 10 sample No. 1, 11 sample No. 1; (12): Assipetra terebrodentarius, sample No. 1; $(13,14)$ : Didemnum minutum, 13 sample No. 1, 14 sample No. 4; (15): Nannoconus kamptneri, sample No. 9; (16): Nannoconus sp. sample No. 12. 


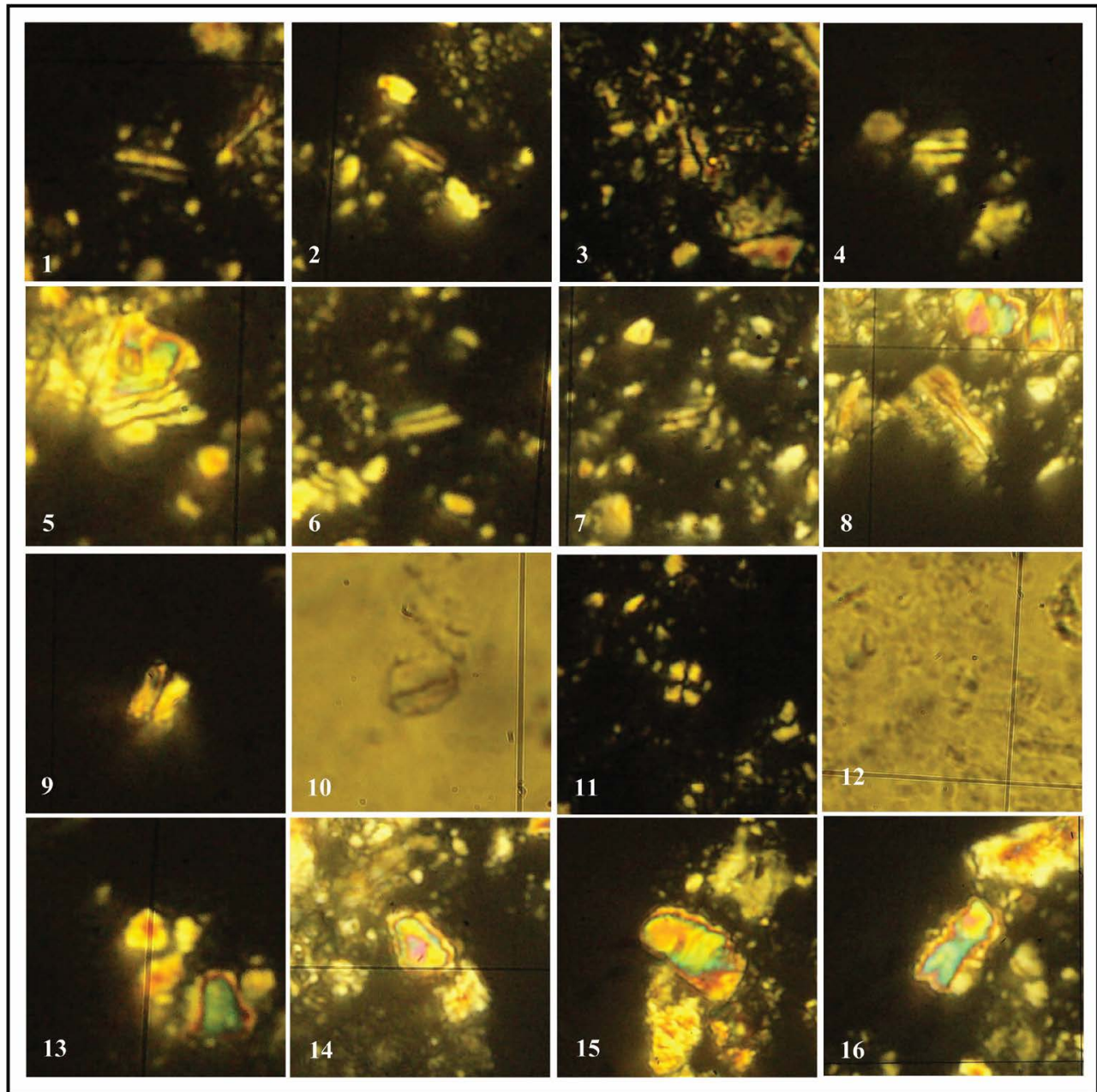

Plate 2. All figures $\times 1250$. (1-8): Lithraphidites bollii, 1 sample No. 2, 2 sample No. 5, 3 sample No. 9, 4 sample No. 6, 5 sample No. 1, 6 sample No. 4, 7 sample No. 6, 8 sample No. 5; $(9,10)$ : Nannoconus dolomiticus, 9 sample No. 5, 10 sample No. 2 ; (11, 12): Watznaueria biporta, 11 sample No. 1, 12 sample No. 1; (13): Tetralithus pseudotrifidus, sample No. 6; (14-16): Nannoconus bucheri, 14 sample No. 6, 15 ample No. 4, 16 sample No. 11.

sils biozone CRETARHABDUS LORIEI (CC 4) in the Jozak section with Early Hauterivian eage. This zone was proposed by Sissingh [10]. The base of this zone is defined as the first occurance (FO) of Cretarhabdus loriei and the last occurance (LO) of Speetonia colligata defines the top of the zone.

Remarks: The FO of Chiastozygus striatus is used in the Boreal realm as a substitute marker for $C$. loriei. Sissingh suggested [10] a subdivision of CC 4 by the LO of Biscutum salebrosum. This has been found to be an unreliable event, since $B$. salebrosum was found by several authors in the Barremian and the Aptian/Albian. PerchNielsen [11] suggested the FO of Eprolithus antiquus and the LO of Cruciellipsis cuvillieri as additional events to subdivide the Hauterivian in the Boreal realm. She also used the LO of Chiastozygus striatus as a substitute marker event for the top of CC 4. Thierstein [12] had used the FO of Lithraphidites bollii and the LO of $C$. cuvillieri for the subdivision of the Hauterivian in the Tethyan realm. L. bollii was not found in the Boreal realm.

In this boundary, Cretarhabdus loriei was absent but $L$. bollii is present, therefore according to Thierstein [12] the age of the studied thickness is Early Hauterivian.

\section{Nannofossils Diversity and Abundance}

Abundant nannofossil assemblages and their occurrence in shallow, neritic settings in the Early Cretaceous tropics migration events into other eutrophic settings may have occurred during periodic warming intervals [13].

In the uppermost Mozduran Formation, 17 species were identified (Tables 1, 2). In spite of the indurated lithology of the Mozduran and Shurijeh Formations, Nannofloras are moderately preserved and relatively low in diversity in this boundary. In these intervals, the low nannofossil total abundances, and the poorly diversified 


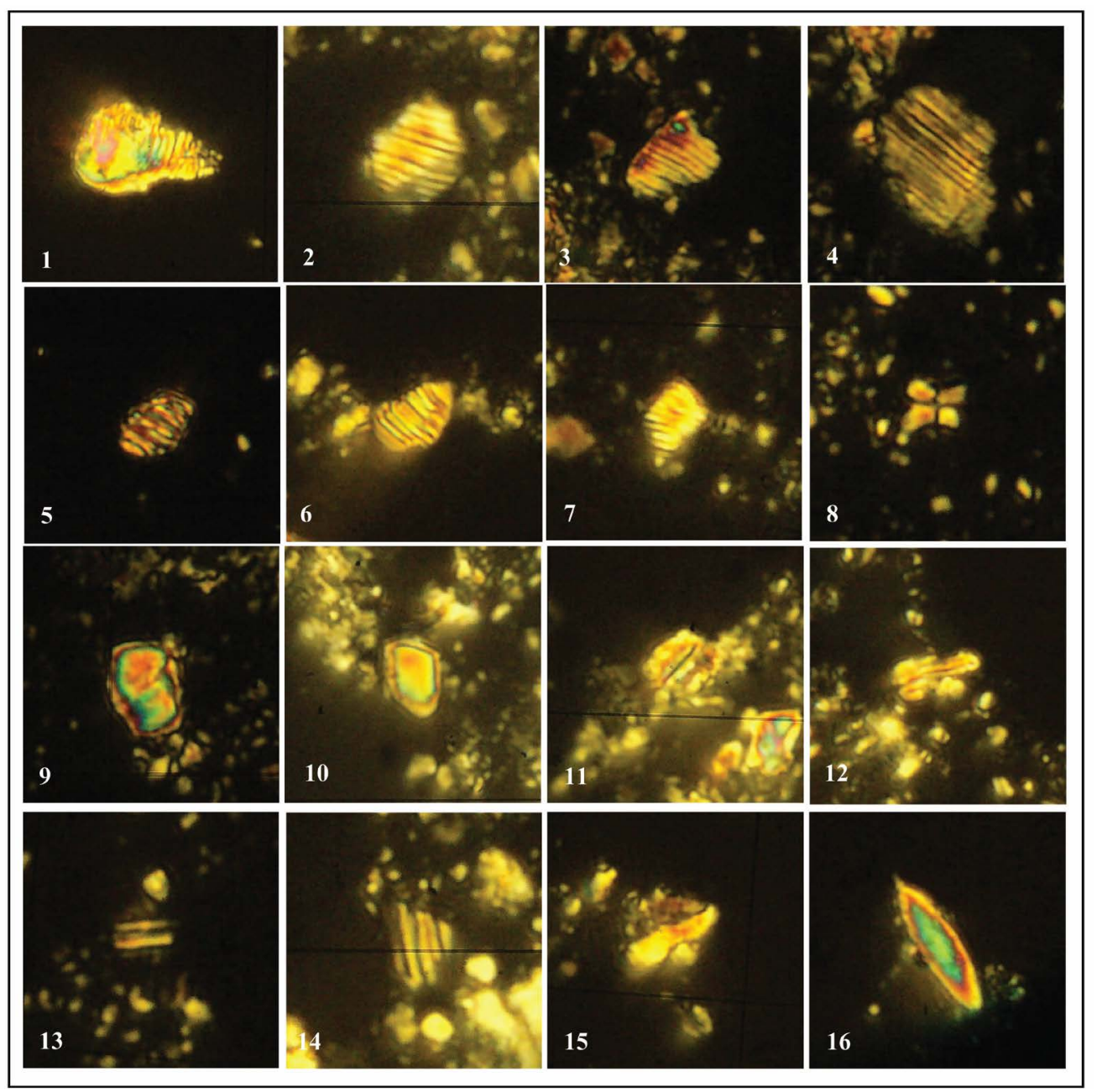

Plate 3. All figures $\times 1250$. (1): Nannoconus colomii, 1 sample No. 3; (2-7): Calcicalathina alta, 2 sample No. 6, 2 sample No. 4 , 3 sample No. 9, 4 sample No.10, 5 sample No. 12, 6 sample No. 2, 6 sample No.7; (8): Tetralithus cassianus, 8 sample No. 3 , (9, 10): Nannoconus bucheri, 9 sample No. 8, 10 sample No. 2; (11): Nannoconus dolomiticus, 11 sample No. 2; (12, 13): Lithraphidites bollii, 12 sample No. 5, 13 sample No. 10; (14): Conusphaera Mexicana, 14 sample No. 5; (15): Didemnum minutum, 15 sample No. 4; (15): Scapholithus fossilism, sample No. 6.

nannofossil assemblages are probably indicative of unfavorable conditions in the water column [14]. The abundance of all species does not follow a general pattern as some species tend to increase or decline from base to top. The most common genera within the assemblage are Nannoconus. In addition, Some species belonging to the genera Watznaueria, Zeugrhabdotus, Tetralithus, Assipetra, Calcicalathina, Conusphaera and Lithraphidites are present in the assemblage but occurred only sporadically with relatively low percentage (Tables 1,2$)$.

\section{Palaeoecology}

Calcareous nannoplanktons are widespread in the recent oceans, from coastal areas to open ocean settings. The distribution of calcareous nannoplankton is intimately linked to climatic zones and climate changes [15]. In the present studies the following results obtained based on the abundance species of calcareous nannofossils.

\subsection{Fertility Indices}

It has been demonstrated that calcareous nannofossil fertility can play an important role in the reconstruction the paleoenvironmental settings. Some nannofossil species are good indicators of surface water fertility. Biscutum spp. (mainly B. constans and B. ellipticum) and Zeugrhabdotus spp. (mainly Z. erectus) are considered as indicators of high surface water fertility in unstable environments such as oceanic sites of upwellingor shelf areas where trophic conditions may have been enhanced by storm mixing or by runoff [16]. However, Biscutum (mainly B. constans) is considered as an indicator of less eutrophic conditions than Zeugrhabdotus spp. [17]. Cretarhabdus spp., T. orionatus and Nannoconus spp. are classified as indicators of low fertility conditions by dif- 
Table 1. Abundance table of the recognized calcareous nannofossil species in samples from the uppermost Mozduran Formation in the the Jozak section.

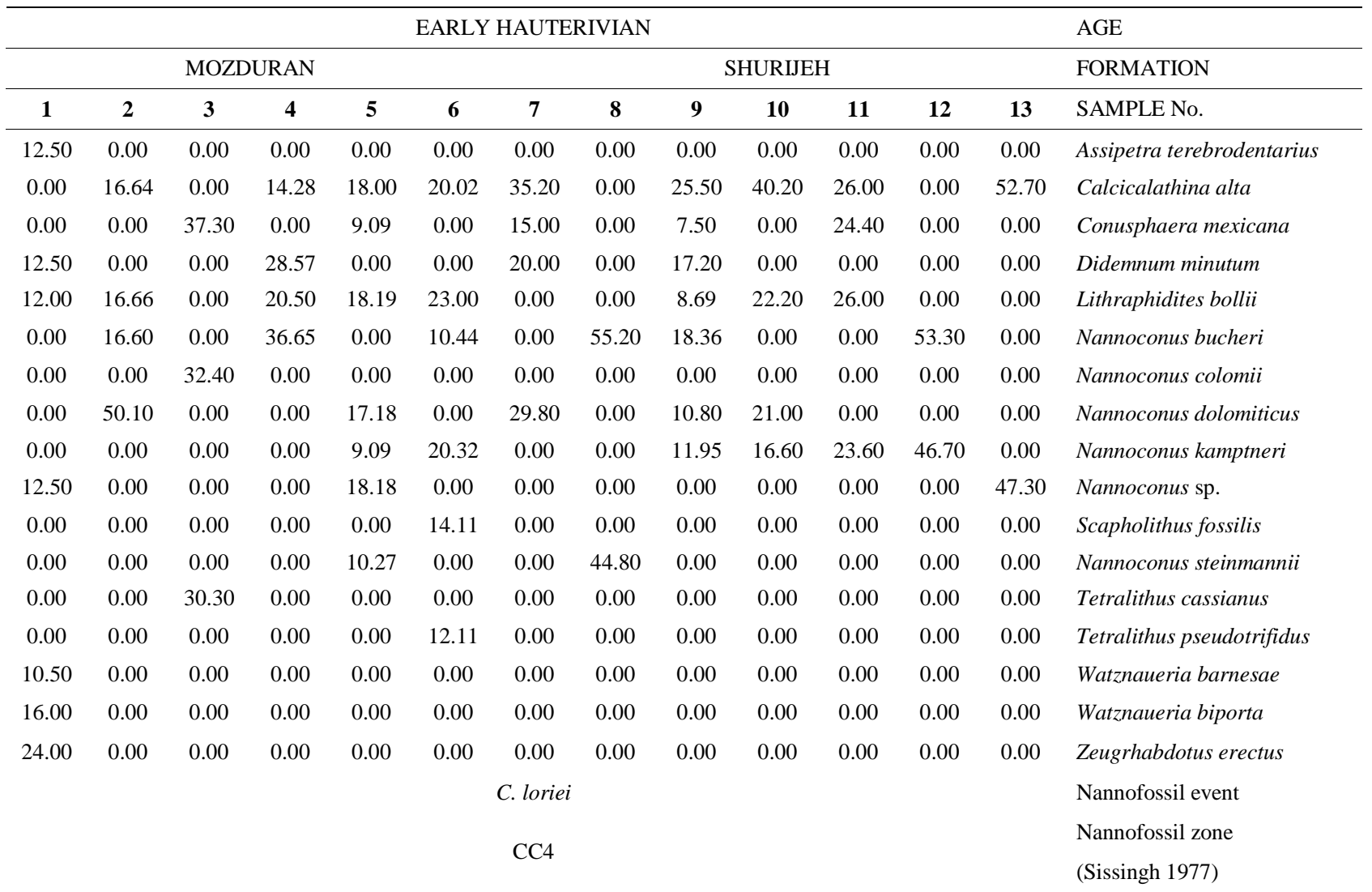

Table 2. Distribution of calcareous nannofossils in the uppermost Mozduran Formation from the Jozak section.

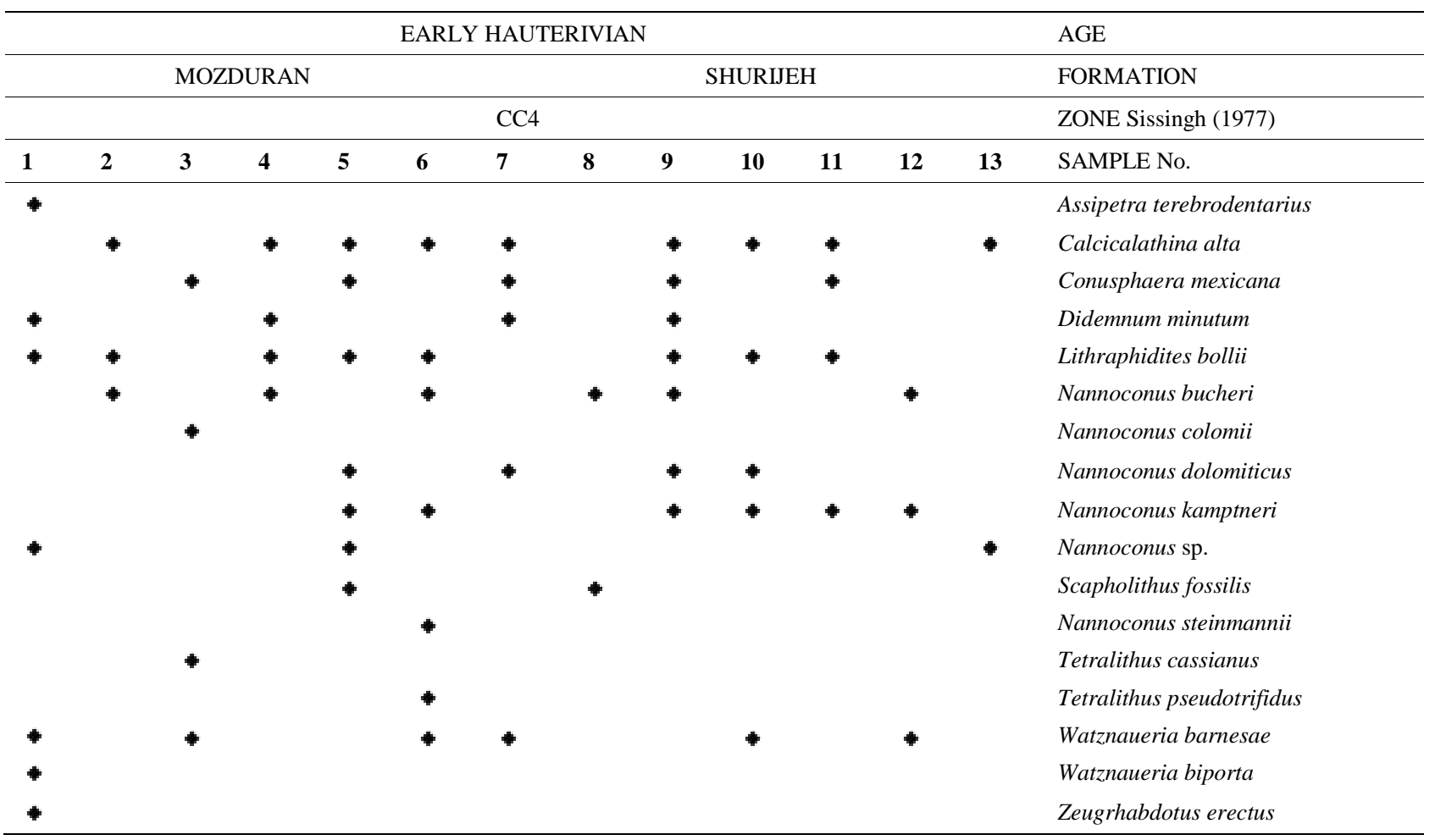


ferent authors $[16,18]$. Nannoconus spp. is the most abundant nannofossil group in all samples examined in this study but Biscutum spp. were absent and Zeugrhabdotus spp. were very rare. According to abundance of nannofossil assemblage in the Jozak section, were suggested that the basin supported a restricted nannoflora, dominated by shelf-adapted taxa with low fertility conditions of surface waters.

\subsection{Depth}

The limiting role of water depth may be explained by a number of interrelated neritic factors including environmental stability, turbulence, transparency, salinity, and nutrients or even water depth itself if the organism had a benthic life-cycle stage [19]. The reasonably comprehensive Early to Mid-Cretaceous biogeographic data suggest there is now little doubt that the paleoecology of nannoconids was in some way related to water depth Nannoconus spp. has been interpreted as restricted to the lower photic zone and to be controlled by fluctuations of the depth of the nutricline [20]. Consequently, changes in abundance of nannoconids and other coccoliths have been used to reconstruct the fertility of surface waters and nutria cline dynamics. High abundances of Nannoconus spp. may indicate a deep chlorophyll maximum zone (DCM) with an increased productivity in the lower photic zone [21]. Therefore, based on the high abundances of Nannoconus spp., the Mozduran and Shurijeh Formations were deposited in the relatively shallow marine environment.

\subsection{Temperature and Latitudinal Distribution}

Various species of Mesozoic calcareous nannofossils have different temperature ranges [22] Cosmopolitan taxa like Watznaueria barnesae covered a broad temperature range, being common both in the low and the high latitudes throughout most of the Mesozoic. Watznaueria barnesae was common in tropical and subpolar regions and may thus be viewed as a eurythermal taxon [23]. Other groups (e. g. Nannoconus, Conusphaera, Micula) are most common in low latitudinal settings where they were partly rock forming. Since they are rare in the Boreal Realm they have often been interpreted as Tethyan warm water taxa [24]. Some cold water taxa (e. g. Stephanolithion, Biscutum, Crucibiscuturn, Repagulum parvidentatum, Seribiscutum primitivurn, Sollasites falklandensis, Ceratolithina, Kamptnerius, Nephrolithus) show restricted palaeobiogeographic distribution patterns. These taxa are most common only in the high latitudes [25].

The diverse assemblages of the low latitudes are dominated by Watznaueria spp., Rhagodiscus asper, Nannoconus spp., Micrantholithus spp. and Conusphaera spp.
These thermophile warm water taxa $[17,26]$ indicate relatively warm surface water temperatures of the tropics and subtropic. These evidences suggest warm surface water conditions and relatively low-middle latitude in the uppermost Mozduran Formation in the Jozak section.

\section{Comparison of Calcareous Nannofossils in the West and East Kopet-Dagh}

According to biostratigraphic studies, in the east KopetDagh, 19 species belonging to 12 genera of calcareous nannofossils were recognized from the uppermost Mozduran Formation in the Mozduran section and 19 species belonging to 13 genera in the Taherabad section. No calcareous nannofossils were found in the lower part of the Shurijeh Formation [2]. But In the Jozak section 17 nannoplanktonic species of 10genera were identified from Mozduran and Shurijeh Formations (Tables 1, 2), unlike the east Kopet-Dagh, Calcareous nannofossils existed in the Shurijeh Formation in the west Kopet-Dagh, therefore, we conclude that environmental conditions in the Mozduran and the Taherabad sections in the east of Kopet-Dagh were better for calcareous preservation nannofossils than the west of Kopet-Dagh.

palaeoecological Comparison of the uppermost Mozduran Formation in the Jozak section in the west and Mozduran and Taherabad sections in the east KopetDagh shows low fertility conditions, relatively low latitude, warm water condition and shallow marine environments. Based on Calcareous nannofossils, the uppermost Mozduran Formation is assignable to Sissingh's (1977) [10] biozone CC1 (Early Berriasian) at the Mozduran section and to biozone CC3 (Late Valanginian) at the Taherabad section in the east [2] and biozone CC4 (Early Hauterivian) at the Jozak section in the west, indicating that the age of the top of the Mozduran Formation is diachronous across the basin and the uppermost Mozduran Formation is younger from east to west in the Kopeh-Dagh basin.

\section{Conclusion}

In this study, 17 species were identified in the boundary between Mozduran and Shurijeh Formations in the Jozak section. As the result of biostratigraphic studies, a biozone is suggested which is equivalent to CC4 of Sissingh [10]. In the base of this zone, the age of studied thickness is Early Hauterivian. According to the studies, the nannofossil assemblages show moderately preservation and the abundant variation of species suggests that the Mozduran and Shurijeh Formations were deposited in the relatively shallow marine environments in low to middle latitudes with warm surface water and low fertility conditions. 


\section{REFERENCES}

[1] J. Stöcklin, "Structural History and Tectonics of Iran: A Review," Bulletin of the American Association of Petroleum Geologists, Vol. 52, No. 7, 1968, pp. 1229-1258.

[2] F. Hadavi and L. Khodadadi, "Nannos Tratigraphy and Palaeoecology of Uppermost Mozduran Formation in the Kopeh-Dagh Range (NE Iran),” Arabian Journal of Geoscience, Vol. 5, No. 6, 2013, pp. 70-71. http://dx.doi.org/10.1007/s12517-013-0839-z

[3] J. Stöcklin, "Stratigraphic Lexicon of Iran,” Ministry of Industry and Mines, Geological Survey of Iran, Report No. 18, 1971.

[4] A. A. Harb, "The Stratigraphy, Tectonics and Petroleum geology of the Kopet-Dagh Region, Northern Iran,” Ph.D. Thesis, London University, London, 1979.

[5] H. R. Thierstein, "Mesozoic Calcareous Nannoplankton Biostratigraphy of Marine Sediments," Marine Micropaleontology, Vol. 1, 1976, pp. 325-362. http://dx.doi.org/10.1016/0377-8398(76)90015-3

[6] K. Perch-Nielsen, "Mesozoic Calcareous Nannofossils," In: H. M. Bolli, J. B. Saunders and K. Perch-Nielsen, Eds., Plankton Stratigraphy, Cambridge University Press, Cambridge, 1985, pp. 329-426.

[7] J. R. Williams and T. J. Bralower, "Nannofossil Assemblages, Finefraction Stable Isotopes, and the Paleoceanography of the Valanginian-Barremian (Early Cretaceous) North Sea Basin,” Paleoceanography, Vol. 10, No. 4, 1995, pp. 815-839.doi.org/10.1029/95PA00977

[8] J. L. Shamrock, D. K. Watkins, "Evolution of the Cretaceous Calcareous Nannofossil Genus Eiffellithus and Its Biostratigraphic Significance,” Cretaceous Research Journal, Vol. 30, No. 5, 2009, pp. 1083-1102. http://dx.doi.org/10.1016/j.cretres.2009.03.009

[9] F. Giraud, D. Olivero, F. Baudin, S. Reboulet, B. Pittet, O. Proux, "Minor Changes in Surface-Water Fertility across the Oceanic Anoxic Event 1d (latest Albian, SE France) Evidenced by Calcareous Nannofossils,” International Journal of Earth Sciences, Vol. 92, No. 2, 2003, pp. 267284.

[10] W. Sissingh, "Biostratigraphy of Cretaceous Calcareous Nannoplankton,” Geologie en Minjbouw, Vol. 56, No. 1, 1977, pp. 37-65.

[11] K. Perch-Nielsen, "Calcareous Nannofossils from the Cretaceousbetween the North Sea and Mediterranean," Aspekte der kreideEuropas IUGS series A, Vol. 6, No. 2, 1979, pp. 223-272.

[12] H. R. Thierstein, "Mesozoic Calcareous Nannoplankton Biostratigraphy of Marine Sediments," Marine Micropaleontology, Vol. 1, 1976, pp. 325-362. http://dx.doi.org/10.1016/0377-8398(76)90015-3

[13] N. Thibault and S. Gardin, "Maastrichtian Calcareous Nannofossil Biostratigraphy and Paleoecology in the Equatorial Atlantic (Demerara Rise, ODP Leg 207 Hole 1258A)," Revue de Micropaléontologie, Vol. 49, No. 4, 2006, pp. 199-214. doi.org/10.1016/j.revmic.2006.08.002

[14] C. Street and P. R. Bown, "Palaeobiogeography of Early Cretaceous (Berriasian-Barremian) Calcareous Nannoplankton,” Marine Micropaleontology, Vol. 39, No. 1-4,
2000, pp. 265- 291.

http://dx.doi.org/10.1016/S0377-8398(00)00024-4

[15] E. Erba, "The First 150 Million Years History of Calcareous Nannoplankton: Biosphere-Geosp Here in Teracions,” Palaeogeography Palaeoclimatology Palaeoecology, Vol. 232, No. 3, 2006, pp. 237-250. http://dx.doi.org/10.1016/j.palaeo.2005.09.013

[16] P. H. Roth and K. R. Krumbach, "Middle Cretaceous Nannofossil Biogeography and Preservation in the Atlantic and Indian Oceans: Implications for Palaeoceanography,” Marine Micropaleontology, Vol. 10, No. 1-3, 1986, pp. 235-266.

http://dx.doi.org/10.1016/0377-8398(86)90031-9

[17] E. Erba, F. Castradori, G. Guasti and M. Ripepe, "Cacareous Nannofossils and Mi lankovitch Cycles: The Example of the Gault Clay Formation (Southern England)," Palaeogeography, Palaeoclimatology, Palaeoecology, Vol. 93, No. 1-2, 1992, pp. 47-69.

http://dx.doi.org/10.1016/0031-0182(92)90183-6

[18] D. K. Watkins, "Nannoplankton Productivity Fluctuations and Rhythmicallybedded Pelagic Carbonates of the Greenhorn Limestone (Upper Cretaceous),” Palaeogeography, Palaeoclimatology, Palaeoecology, Vol. 74, No. 1-2, 1989, pp. 75-86. http://dx.doi.org/10.1016/0031-0182(89)90020-5

[19] G. Busson and D. Noël, "Les Nannoconidés Indicateursenvironnementaux des Oceans et Mers Épicontinentales du Jurassique Terminal et du Crétacé Inférieur,” Oceanologica Acta, Vol. 14, No. 4, 1991, pp. 333-356.

[20] J. O. Herrle, J. Pross, O. Friedrich and C. Hemleben, "Short-Term Environmental Changes in the Cretaceous Tethyan Ocean: Micropalaeontological Evidence from the Early Albian Oceanic Anoxic Event 1b,” Terra Nova, Vol. 15, No. 1, 2003, pp. 14-19.

http://dx.doi.org/10.1046/j.1365-3121.2003.00448.x

[21] E. Erba, "Nannofossils and Superplumes the Early Aptian Nannoconid Crisis,” Paleoceanography, Vol. 9, No. 3, 1994, pp. 483-501. http://dx.doi.org/10.1029/94PA00258

[22] A. Lees, "Calcareous Nannofossils Biogeography Illustrates Palaeoclimate Change in the Late Cretaceous Indian Ocean,” Cretaceous Research, Vol. 23, No. 5, 2002, pp. 537-634. http://dx.doi.org/10.1006/cres.2003.1021

[23] J. Mutferlose, “Calcareous Nannofossit Palaeoceanography of the Early Cretaceous of NW Europe,” Mitteilungen aus dem Geologischen Staatsinstitut in Hamburg, Vol. 77, 1996, pp. 291-313.

[24] J. Mutterlose, "Biostratigraphy and Palaeobiogeography of Early Cretaceous Calcareous Nannofossils," Cretaceous Research, Vol. 13, No. 2, 1992, pp. 167-189. http://dx.doi.org/10.1016/0195-6671(92)90034-N

[25] J. Mutterlose, A. Bornemann and J. O. Herrle, "Mesozoic Calcareous Nannofossils-State of the Art," Paläontologische Zeitschrift, Vol. 79, No. 1, 2005, pp. 113-133. http://dx.doi.org/10.1007/BF03021757

[26] E. Erba, "Mid-Cretaceous Cyclic Pelagic Facies from the Umbrian-Marchean Basin: What Do Calcareous Nannofossils Suggest?” International Nannoplankton Association Newsletters, Vol. 9, No. 4, 1987, pp. 52-53. 